\title{
Classical Islamic Discourse on the Origins of Language: Cultural Memory and the Defense of Orthodoxy
}

\author{
Mustafa Shah \\ School of Oriental and African Studies, London University \\ Russell Square, London WC1H OXG England \\ ms99@soas.ac.uk
}

\begin{abstract}
Classical Islamic scholarship developed two principal theses on the subject of the origin of language (asl al-lugha). The first of these theses, commonly referred to as tawqif, accentuated the pre-eminent role that divine agency played in the imposition of language; axiomatic within this perspective is the view that words (lafz pl. alfäz) have been assigned their meanings ( $m a^{\prime} n \bar{a}$ pl. $m a^{\prime} \bar{a} n \bar{\imath}$ ) primordially by God. Presented as something of an antithesis to this position, the second doctrine, labeled isțiläh, predicates that language was established and evolved via a process of common convention and agreement: words together with their meanings were assigned by human beings, although both the doctrines of tawqif and istilath posit that the actual relationship between words and their assigned meanings remains entirely arbitrary, rejecting any sort of natural link between the two. Although later Islamic scholarship accepted that both theses were plausible, within the course of the 9th/10th centuries opinions on the subject were ostensibly polarized between orthodox and arch-rationalist camps with the former endorsing tawqif and the latter iștilăh. In the quest to achieve a conceptual defense of traditional arguments for tawqîf it was necessary for orthodox theologians to create a connective structure, as articulated through reference to remembrance, continuation, and identity, which enabled them to anchor the construct of tawqi $f$ in a formalized way to the scriptural exegesis and emblems of orthodoxy associated with the pious ancestors. That this was successfully accomplished through references to the past would seem to confirm the role which cultural memory played in the defense of what was deemed an orthodox belief.
\end{abstract}

\section{Keywords}

Islam, origins of language, Arabic grammarians, orthodoxy, Mu'tazilites, Ash 'arism 


\section{Introduction}

Classical Islamic scholarship developed two principal theses on the subject of the origin of language (asl al-lugha). The first of these theses, commonly referred to as tawqif, accentuated the pre-eminent role which divine agency played in the imposition of language; axiomatic within this perspective is the view that words had been primordially assigned meanings by God. The modality of this process of positing is never fully qualified, although it is hypothesized that God created a necessarily intuitive knowledge which encompassed words and their assigned meanings. Presented as an antithesis to this concept, the second thesis, labeled iștiläh, predicates that language was established via common convention and agreement (muwäda'a) by humans who assigned communicative meaning to words. Both the doctrines of tawqif and istilath deem that the original formation of the connection between words and their meanings remains entirely arbitrary (Suyūtīi 1970:I, 1-60). There does not exist an absolute affinity between the distinctive phonemic properties of the Arabic word for "book," kitäb, and the physical object it signifies. Indeed, it would have been entirely conceivable for the inventor of language to choose an alternative combination of phonemes to denote "kitäb." The terms revelationist and conventionalist are frequently used to signify the respective tawqif and isțiläh theses. Recent scholarship has identified an intricate range of theological exigencies and concerns which were driving the early debates on the origins of language, arguing that the thesis of istiläh was generated within the course of such discussions. It is also reckoned that, concomitantly, tawqiff, despite having tentative roots in early exegetical musings, appears in a much more developed sense as a significant counterargument adduced to challenge and undermine iștiläḥ and the range of theological doctrines aligned with it.

Initially, elements within orthodox Islamic circles tended to endorse the thesis of tawqif , despite the fact that a number of its advocates were individuals not necessarily renowned for their orthodox inclination. Gradually, as the theological trajectories of the discourse evolved, both theses were recognized as being equally plausible; indeed, some scholars even adapted elaborate explanations of the origins of language which fused peculiar aspects of the two doctrines (Zarkashì 1992:II, 14-16). Nevertheless, in the course of the 9th/10th centuries and for a period 
beyond, opinions on the subject were more or less entrenched and indicative of an underlying theological tension between traditionalists and arch-rationalists. And, in the quest to achieve a conceptual defense of traditional arguments for tawqif, it was necessary for orthodox theologians to create a connective structure, as articulated through reference to "remembrance," "continuation," and "identity," which enabled them to anchor the construct of tawqif in a formalized way to the scriptural exegesis and emblems of orthodoxy associated with the pious ancestors. That this reconstruction was successfully accomplished through references to the past would seem to confirm the measured role which cultural memory played in the defense of an orthodox idea.

\section{Historical contexts}

Classical Muslim sources referring to the discussion of the origins of language frequently affirm that the doctrine of istilāh was first introduced by Abū Hāshim ibn al-Jubbāì ì (d. 933), a distinguished theologian. His father, al-Jubbāî̀ (d. 915), was one of the outstanding members of the Basran Mu'tazilites, a theological movement which had its historical roots in the early Islamic tradition. The Mu'tazilites were renowned for upholding the critical role that human reason should play in the synthesis of faith, importing rationally based arguments and premises to define and defend their doctrinal stances. The Mutazilites insisted that God always acted in accordance with the dictates of reason (' $a q l$ ), which, in their view, had to serve as the principal criterion and arbiter of truth; they assimilated Greek philosophical arguments and constructs which had gradually pervaded the intellectual discourses of the Islamic world through a steady stream of translations into Arabic via Syriac. They referred to themselves as the upholders of "divine unity and justice," promoting two key axioms. Firstly, they defended the notion of God's absolute transcendence, dismissing any attempt to conceptualize or refer to the divine essence in an anthropomorphic way. Additionally, they argued that God's attributes, as predicated in the scriptural sources, were an intrinsic part of his essence in the sense that God knows not by a hypostatic entity of knowledge which subsists within his essence, but by virtue of his unique essence; these attributes 
were identical with His essence; they were identical with Him (Mānkdīm 1965:182-3 cf. Juwaynī 1996:51-5). Within orthodoxy these attributes, among which is the attribute of speech (kalam), were viewed in a substantial and essential vein. The Mutazilites contended that such a view implied the existence of a plurality within the Godhead, compromising the conception of the divine unity of God. Secondly, they trenchantly rejected the orthodox doctrine of predestination, insisting that God's divine justice together with the prerequisites of moral and religious obligation entailed that human beings had to be free and responsible agents who were the sole authors of their acts.

In stressing the axiom of God's transcendence, the Mu tazilites argued that the sacred scripture of Islam, the Qur'ann, was a created and temporally contingent document; there was a time when it did not exist. The traditional belief predicated that the Qur'an was the uncreated and essential speech of God (kaläm Allāh) as revealed to his Prophet by the angel Gabriel and that to speak of the Qur'ān in terms of its being created compromised this exceptional quality. Some staunchly traditionalist theologians had claimed the Qurān was eternal (qadim) and uncreated in status and that the attribute of speech together with its physical expression (lafz) as a recited text was actually coordinate with the divine essence; others had simply emphasized its entitative and concomitant status within the divine essence (Juwaynī 1996:128-9). But for the Mu'tazilites, to refer to God as a speaker in any sort of literal context was tantamount to anthropomorphism and also implied that He possessed a physical organ with which words were articulated (Madelung 1974:507). It would have been argued from an ontological perspective, that such an understanding contradicted the nature of God's transcendence and the reality that the divine essence could not serve as a locus or substrate for contingent acts such as speech or indeed even physical movement. During the period referred to as the mihna ("Inquisition"), when the political influence of the Mu'tazilites was dominant, the doctrine of a created Qur'àn was imposed as the official policy of the 'Abbasid state by the caliph al-Ma'mūn (ruled 813-33). It was vigorously opposed by traditionalist scholars, who were in some cases compelled to recant the doctrine of an uncreated Qur'ān.

Historically, al-Jubbāî̀ was closely associated with Abü' 1-Hasan al-Ash arī (d. 935), the eponym of Sunni orthodoxy's most prominent 
school of scholastic theology, the Ash arites. ${ }^{1}$ Doctrinal disagreements between these two cynosures led to al-Ash arī denouncing the Mu'tazilites, and subsequently devoting his life to refuting their theological teachings and arguments. While differences persist as to whether the brand of orthodoxy which became synonymous with later Ash arite thinkers has its roots in the legacy of al-Ash 'arī, it was purposefully constellated around a rationally based traditionalist methodology and strategy to counter Mu'tazilism (Frank 1991:143-9; Makdisi 1962:37-41). One tension in medieval Islamic thought is the opposition between traditionalists on the one hand, who abhorred the use of speculatively based rational tools for the defense of orthodoxy, and, on the other hand, the Ash arites, who were content to utilize such rational approaches and procedures when mounting a defense of orthodoxy. This was not merely an issue of methodology and approaches; rather, there were key points of dogma which inexorably separated the traditionalists, especially those with conservative outlooks, from the Ash'arites. Despite the opprobrium of the staunch traditionalists, rationally inspired approaches to the defense of religious dogma became an indelible feature of classical Islamic theological discourse. The thematic compass of theology extended to a gamut of subjects: it was concerned not only with the articulation of traditional beliefs, but it also took to expanding constructs of dogma which were the product of dialectical discussions and debates (Shah 2007:432-5). This sometimes entailed the controversial use of apophatic and cataphatic forms of argumentation and, moreover, reference to teleological and cosmological arguments (Āmidī 2004 passim). The accusation that the Ash arites were tainted through their promoting a brand of Mu'tazilism masquerading as orthodoxy frequently resonates in the classical theological literature. Nonetheless, this should not detract from the fact that the opposition between the Mu'tazilites and the Ash arites forms a fecund chapter in classical theological thought. Much of the discussion about the origins of language was inspired by the intellectual milieu of deliberations between the

1) The brand of orthodox scholastic theology cultivated by Ash 'arī had its antecedents: figures such as Ibn Kullāb (d. 854), al-Qalānisī (fl. 9th century), and al-Muhāsibī (d. 857) were linked with adopting similar strategies in the defence of orthodoxy. Ibn Kullāb's followers were identified with a separate school (Kullābiyya). 
Mu'tazilites and the Ash arites, although contributions to the debate came from other quarters within the religious tradition. In the related literature references to the origin of language often appear to be a peripheral feature of theological and legal discourses, although the discussions had profound ramifications for a number of contentiously debated topics, including the doctrine of the divine names, arguments about the imposition of religious obligation, theological references to metaphor and figurative language, and, to an extent, the concept of a created Qur'ān.

Following a period of gestation, the Mu'tazilites divided into two nominal camps: the Basrans and the Baghdādīs, although the indigenous influence of these camps extended across different parts of the Islamic world (Van Ess 1987:6320; Watt 1998:217-50). In the Basran camp were figures such as Ḍirār ibn 'Amr (d. 915), Abū Bakr al-Aṣamm (d. 816), Abū 'l-Hudhayl al-'Allāf (d. 841), al-Nazzām (d. 836), Mu'ammar ibn 'Abbād (d. 830), Hishām ibn 'Amr al-Fuwatị (d. 842), al-Jāhị (d. 869), and 'Abbād ibn Sulaymān (d. 864). The Baghdādīs included among their ranks Bishr ibn al-Mu'tamir (d. 825 or 840), Thumāma ibn Ashras al-Numayrī (d. 828), Ja far ibn Harb (d. 850), and other notable individuals. Despite the existence of differences on specific points of doctrine among these figures, the underlying principles of "divine unity and justice" and the doctrine of the created Qur'àn were key shibboleths of Mu'tazilism; and significantly, the whole dynamic of this movement's thought was incontrovertibly driven by a rationally inspired synthesis of dogmatic and dialectical constructs.

\section{Arguments for tawqīf and iștilāh}

During the chronological era in which Abū Hāshim lived, the movement associated with the Mu'tazilites had relinquished much of its political influence, but continued to develop theoretical ideas and solutions to various theological quandaries and related discussions throughout the ensuing historical periods. Despite the fact that none of Abū Hāshim's oeuvre has survived, a range of dicta and reports attributed to this figure and others on the subject of tawqif and iștiläh is preserved in theological, philological, exegetical, and legal literature, particularly 
those texts devoted to the principles of jurisprudence in which scholars pored over the epistemological preliminaries of language as a prelude to defining the theoretical bases of law. By virtue of these materials it is possible to gauge the various arguments and counter-arguments which surface in discussions relating to the origins of language. There is scant evidence to show that the concept of iștilă $h$ was articulated before being championed by Abū Hāshim. ${ }^{2}$ Critically, once the concept of iștilăh was proposed, it appears to have been immediately countered with the thesis of tawqîf by Abū Hāshim's father, al-Jubbāìn, Abū 'l-Qāsim (al-Balkhī) al-Ka'bī (d. 932), a renowned Mu'tazilite of the Baghdādī school, and Abū 'l-Hasan al-Ash'arī (Naysābūrī 1979:158).

The earliest extant Mu'tazilite theological sources which feature a detailed treatment of the issue are the writings of al-Qādịi 'Abd al-Jabbār (d. 1025), a trenchant defender of Mu'tazilism in whose works is preserved much of this school's thought from the formative periods. Among his most important work is the Kitäb al-mughnī, a voluminous text which covers a grand collection of theological subjects. The followers of Abu Hāshim are referred to in the sources as the Bahshamiyya, representing the predominant branch of the school in the 10th and 11th centuries. The suggestion is that its brand of theology purportedly dominated the related discourse among Mu' tazilites in these periods (Isfarāyinnī 1985:74). 'Abd al-Jabbār and many of his immediate students were enumerated among the ranks of the Bahshamiyya. It is also clear from the contexts in which Abū Hāshim is cited in the literature that, although iștilāḥ appears as his doctrinal innovation, there are other markedly significant theological concepts which he introduces and propounds upon, underlining his reputation as an immensely influential thinker. ${ }^{3}$

The analysis of the topics of istiläh and muwäda'a features at a number of junctures in the Kitäb al-mughnī, but in a chapter devoted to a discussion of the names and attributes of God 'Abd al-Jabbār broaches the premise that initially a name (ism) can represent only its named entity or referent (al-musammā) by way of meaningful designation and purpose (qasd wa-irāda) ('Abd al-Jabbār 1965:V, 160-5). He argues

2) Richard Frank does mention that muwāda'a was introduced by Ibn al-Rāwandī (d. 859); Frank 1978:29.

3) This would include his famous theory of hypostatic states ( $a$ havāl), which dealt with the nature of the divine essence. 
that through common convention and agreement entities are assigned names but it is the very act of qasd, that is to say, divulging the design and intended purpose of naming, which primarily validates the connection between a name and its referent. Through a labyrinth of arguments in which Abū Hāshim is often cited, it is postulated that without a necessary awareness of qasd among interlocutors, no process of muwad da' $a$ is possible. The general thrust of this rationale would be that if language had been established initially via tawqif , with God's inventing language and establishing the relationship between words and meanings, then he would have had to reveal necessarily the design and intention behind the use of language. This would entail disclosing to humans knowledge of God before the actual imposition of religious obligation. 'Abd al-Jabbār insists "It is inconceivable that we should necessarily know God's intention in the state of obligation, just as it would be inappropriate to know necessarily His essence at the time when obligation comes into existence" ('Abd al-Jabbār 1965:V, 164; Rāzì 1981:I, 191). The reasoning is that knowledge of the attribute of an entity, in this case God's imposition of language, would a fortiori necessitate knowledge of the essence of that entity, namely God (Asnawi 1999:I, 189). Mu'tazilites insisted that a human being's first duty was to recognize God through rational contemplation: it was not possible to witness God in the physical sense, nor can He be known in an inevitably necessary way (Mānkdīm 1965:44; cf. Juwaynī 1969:110). It was incumbent upon individuals of sound mind to seek to acquire knowledge of God. Referring to Abū Hāshim's arguments, 'Abd al-Jabbār argues that if humans were acquainted with God's qasd, then takliff, the act of imposing religious obligation, would be rendered utterly futile. ${ }^{4}$ From a separate perspective, 'Abd al-Jabbār contends that preceding the process of muwäd ${ }^{\prime} a$, in which words are assigned meanings, were observable acts of gesticulation. These acts permit the specification and designation of the thing named (al-musammā); unsurprisingly, by inference God could not possibly be associated with the physical movement

\footnotetext{
4) Ash arite theologians argued that religious obligations could only be realised following revelation (Juwaynī 1969:115). With respect to 'meaning', de Saussure spoke of the arbitrary nature of the relationship between the signifiant (concept) and the signifié (sound image).
} 
concomitant with such acts ('Abd al-Jabbār 1965:164). Now, 'Abd al-Jabbār does concede that it is possible for tawqif to occur in respect of the genesis of succeeding languages, but this would occur only once an initial language had been established via muwäda' $a$ by humans ('Abd al-Jabbār 1965:V, 164-6; cf. Peters 1976:386-7).

In a later text entitled al-Masä il fìl-khiläf composed by one of 'Abd al-Jabbār's students, Abū Rashīd al-Naysabūrī (d. 1068), in which doctrinal differences between Basran and Baghdādī Mu'tazilites are enumerated, Abū Hāshim is identified as the author of the idea that the origin of language lies in muwāda'a (iștiläh̆). Abū Rashīd maintains that Abū 'l-Qāsim al-Balkhī professed the doctrine of tawqîf, while, conversely, al-Jubbā'i is purported to have recognized that both the doctrines of tawqi f and istiläh offered plausible explanations for the origin of language. Abū Rashīd then moves on to defend the doctrinal position taken by Abū Hāshim, using similar arguments about qașd and taklîf (Naysābūrī 1979:158). Later sources provide further anecdotal evidence of the arguments employed by Abū Hāshim to justify iștilāh (Asnawi 1999:I, 188). One such example is his contention that the human designation of language must precede the advent of revelation. A Qur'anic verse to that effect is cited, Q 14:4: "And never did we dispatch a Prophet except that he conversed in the language of those to whom he was sent in order to make (matters) plain for them." Abū Hāshim is said to have retorted that the alternative would be for God to instill a necessary and intuitive knowledge of language in the mind of an intelligent individual. However, he adds that such an act would necessitate this individual spontaneously recognizing God, rendering futile the concept of religious obligation, taklif (cf. Asnawi 1999:I, 188). Ex hypothesi, a conventionally derived language has to be in place before the advent of revelation (Versteegh 1996b:25).

The key figure who is identified as an opponent of isțilăh and the defender of the thesis of tawqîf, al-Ash arī, is reported to have been a prolific author of works, but only a small number of these is extant and no discussion of the thesis of tawqîf is found in these texts (Ibn 'Asākir 1982:140). The basic theological arguments for tawqif attributed to al-Ash ari are preserved in the literature of later Ash'arite luminaries. One such work is the Mujarrad maqualät al-shaykh Abï'l-Hasan al-Ash'ari ("The essential theological doctrines of Al-Ash arî") composed by one 
of the school's acolytes, Ibn Fürak (d. 1015), and this presents a synoptic survey of the theological doctrines professed by al-Ash 'arī. In this work Ibn Fūrak confirms that al-Ash'arī was of the opinion that all languages were established via tawqiif. He also refers to his having adduced the argument of infinite regress to dismiss istilath on the basis that every stage of positing the communicative meaning of language would necessarily require a preceding phase of muwäda' $a$ ad infinitum: that this is reductive means that the only plausible explanation for the origin of language was that supplied by tawqïf. Ibn Furrak contends that while al-Ash'ari accepted that the very roots of language were established via tawqiff, he conceded that some of the branches of languages could be determined by a process of analogy and applied endeavor (ijtihäd).

Further implications of the discussions on tawqif and isțilāh become apparent when Ibn Fürak reveals that al-Ash arĩ maintained that the divine names of God and His attributes can be determined only by way of tawqif: namely, on the basis of divine instruction and decree, and that this sort of designation had to be referenced to authenticated scriptural sources such as the Qur'ann and the Prophetic traditions, or indeed community consensus (Ibn Fūrak 1987:42). Offering a synopsis of Ash arite doctrine, the 10th century theologian al-Baghdādi discloses that the Basran Mu'tazilites professed the belief that the names of God were derived through a process of istiliāh and qiyās (analogical reasoning), adding that the Sunnites (Ash arites) believed that these divine names had been determined by virtue of tawqîf (Baghdādī, 1928:116; cf. Jurjānī 1998:VII, 232-4). In this context it seems evident that deference to tawqif was one way of countering the Basran arguments regarding the etymology of the divine names; in his critique of the Basran Mu'tazilites' position on the divine names Ibn Hazm (d. 1064), a figure associated with a stricter form of orthodoxy, adopts a similar strategy in terms of invoking tawqī (Ibn Hazm 1985:II, 345-6).

The differences between Ash arites and Mu'tazilites on the issue of the divine names emanate from al-Jubbäî's argument that it was possible to designate these names by way of analogy. Yet, the tawqiffisțiläh antithesis in respect of the origin of language had little to do with al-Jubbä'iss stance on this issue for he subscribed to the view that both tawqîf and iștiläh were equally plausible theses: thus conceptually, 
neither of them would appear to impinge upon his theory apropos the divine names (Frank 1978:29; Vasalou 2009:210-2). Still, it has been argued that the debate on this issue was boldly taken a stage further by Abū Hāshim who created the construct of istilāh to consolidate the arguments for designating divine names by way of analogy (Gimaret 1988:37-50; Vasalou 2009:201-3). From a broader perspective, according to the Mu'tazilite concept of divine unity (tawhìd), the substantive names and attributes associated with God were identical with him, but did not essentially inhere in God's essence in an entitative or hypostatic sense. It would have been argued that initially God had neither name nor attributes $\equiv$ se were created and designated at a later point in time. This whole discussion is related to the idea that there did not exist a unity of identity between names (asm $\vec{a})$ and the referents or entities $(m u s a m m \bar{a})$ which they signified, but rather they were a product of the process of naming (tasmiyya) (Bāqillānī 1993:258; Versteegh 1977:156-61; Burrell and Daher 2004:4-9). Ash'arites recognized that a number of these names and attributes were essential, existing hypostatically within God's essence; they also took the position that there existed a unity of identity between the name and the thing named (nomen and nominatum): in their view the names and attributes manifestly reflected, ontological realities of the divine essence, embodying the qualities defined by their referents (al-Ash 'ari 1990:345; Bāqillānī 1993:258; cf. Ghazāì 2006:9-21). Conversely, by jockeying for position on the etymology of the divine names and appealing to iștiläh, the Mu tazilites could undermine the Ash arite arguments about the nature of the divine essence.

Interestingly, Abū Rashīd al-Naysābūrī’s al-Masä il includes a section which discusses the subject of "changing assigned names," stating that al-Ka bi rejected that this was possible except by virtue of revelation $(w a h y)$. He referred to such changes as having the potential to create ambiguity for those under religious obligation (al-mukallaf). But being faithful to his Bahshamiyya allegiances, Abū Rashīd pronounces that such a convention is acceptable if it has a sound purpose, citing the innovative scheme of terminology applied to the metrification of poetry by Khalīl ibn Aḥmad (d. 791) (Naysābūrī 1979:161). Thus it would seem that the arguments about istilāh favored by the Bahshamiyya were theoretically derived constructs conceived to promote the wider aim of 
a theory about God's divine names, although whether iștilāh was absolutely critical to the concatenation of arguments adduced in this respect remains somewhat vague; this is due to the fact that a number of prominent Mu'tazilite scholars were enthusiastic advocates of tawqif $f$. But the thesis of istiläh̆ was also relevant to arguments about religious obligations, the created status of the Qur'ān, the incidence of metaphor along with its theological import and even the idea that the acceptance of isțiläh would allow changes to the meaning of religious conventions and precedents (Asnawi 1999:I, 186). To deal with this cogent array of theological challenges, some of which were deemed proportionately graver than others, the proponents of orthodoxy had to come up with a robust defense which could engage with the rational arguments propounded by their opponents but, more significantly, also appeal to decisive scriptural proofs.

The arguments among advocates of tawqî and iștilāh proceeded on a number of bases: firstly, there was the attestation of authenticated scriptural proofs, adillat al-sam', which were chiefly Qur'anic in provenance, although it was also possible for scholars to cite an appropriate Prophetic dictum. The adillat al-sam ' would be separately subjected to resolution and explication by the opposing camps. Then, secondly, there were the rational arguments which dealt with demonstrating or challenging the plausibility of constructs; the argument and counterargument adduced by the respective camps often led to a circularity in the discussions. From a traditional perspective a number of factors favored those who were defenders of tawqiif. Proofs from scriptural sources were seemingly closer to a revelationist perspective than a conventionalist one; furthermore, iștilăh was unquestionably an innovative concept introduced at a posterior juncture in the history of Islamic thought. As the "agents of cultural memory" defenders of tawqif could create a meaning from the available scriptural proofs which brought down the scales in favor of their thesis (cf. Assmann 2006:43). The additional qualifying dicta associated with the pious ancestors, which later scholars were able to adduce, further buttressed the case for tawqif. Appealing to the authority of precedent and using the skilful juxtaposition of Qur'anic and extra-Prophetic statements, they placed tawqif firmly within the boundaries of the legacy and teachings of the pious ancestors, presenting the doctrine as a distinction of orthodoxy. And 
within this context, the elementary thesis of tawqif as derived from the corpus of scriptural evidences was "given enhanced normative value" (Assmann 2006:69). The achievement was ingenious for the advocates of tawqif had identified with a derived expression of a traditional past, a past that would enable them to counter isțiläh, a perceived innovation, and the range of doctrines for which it could be exploited (Assmann 2006:28 cf. Brunner 2005:327).

\section{Scriptural evidence}

The Qur'anic verse which served as the locus classicus for the advocates of tawqif was Q 2:31. It states, "And indeed God taught the names (asmä) of all existent things to Ādam; then, he showed them to the angels and announced inform me of the names of these if you are truthful'." For individuals such as the Mālikite jurist Muhammad ibn Khuwazmandād (fl. 10th C) the Qur'anic verse alone provided indubitable proof that language's origin lay in tawqif and that the names taught by God to Âdam encompassed the most general of existent things and the more specific among them (Qurtubì 1988:I, 194). Proponents of istiliāh did attempt to proffer interpretive glosses of these proofs which supported their own perspectives. However, the concomitant attestation of Qur'anic verses and dicta associated with Companions and Successor figures added significant weight to the arguments for tawqïf. Classical exegetical literature is replete with separate reports emanating from distinguished authorities such as Ibn 'Abbās (d. 6878), 'Ikrima (d. 723), Qatāda (d. 735), Mujāhid (d. c. 718 or 722), and Ibn Jubayr (d. 714) in which it is proclaimed that Ādam was taught the names of all things be they significant or otherwise (Tabarī 1969:I, 480-6). Although not concerned with the theoretical intricacies and implications of the arguments about tawqif and iștilāh, the scriptural evidence for tawqif found in exegetical sources appeared to be overwhelming. Still, the traditional exegetical literature also included references to much more confined interpretations of the verse, and among which were statements suggesting that God had taught Ādam only the names of his offspring and the angels; indeed, even the renowned commentator al-Tabarī (d. 922) veered towards this particular explanation 
of the verse (Tabarī 1969:I, 480-6). Despite this, such materials were seemingly adumbrated by proofs endorsing tawqif.

A number of the Qur'anic verses adduced by the proponents of tawqîf are discussed in a Qur'anic commentary by 'Abd al-Jabbār devoted to defending Mu'tazilite doctrine through reference to the class of verses deemed theologically contentious (mutashäbihāt). The text applies an exegesis of the Qur'ān in a way which shows that Mu'tazilite tenets and doctrine are commensurate with the general thrust of scripture, refuting opposing perspectives in the course of its discussions. Regarding Q 2:31, 'Abd al-Jabbār dismisses the suggestion that the verse provides scriptural proof of the validity of the doctrine of tawqif or that it undermines the idea of muwäda'a ('Abd al-Jabbār 1969:82-4 cf. 'Abd al-Jabbār 1965:V, 164-6). He stresses that it implicitly reveals that God did indeed teach Ādam the names of all things, but the language which he was taught had previously been established via muwädàa. Abū Hashim's arguments about qașd and taklïf are prominently highlighted to drive home the point. Similar points are emphasized by Abū Rashīd al-Naysābūrī, who even includes an anonymous statement announcing that the verse in question shows that Âdam was taught by God the phases of muwäda'a which were at some point in the future going to be established by humans; it was implied that Ādam's being presciently acquainted by God with this anticipated muwäda'a could serve as a divine miracle (Naysābūrī 1979:161).

The appeal to scripture did not end there and in the numerous treatises which dealt with the arguments on this topic, advocates of tawqif cited further Qur'anic verses. One of these refers to polytheists having invoked the names of gods whom they had themselves invented: the Qur'ān condemns this practice more than once: both Q 12:41 and Q 53:23 state, "These are merely names you and your forebears invented and concerning which God has provided no sanction." The reasoning here is that the misguided naming and identification of such deities was grossly artificial and erroneous; this was an inherent indictment of isțiläh, indicating that language had been revealed via tawqîf (Asnawi 1999:I, 185-7). A further relevant verse is Q 30:22 which asserts "And among his signs are that he created the heavens and the earth; and (also) the diversity of your tongues (languages) and colors." For the proponents of tawqiff, the upshot of this verse was irrefutable: the diversity 
of these languages is enumerated among the bounties and blessings bestowed by God upon humanity, providing further proof of the preponderance of the doctrine of tawqîf. But 'Abd al-Jabbār retorts that some argue that the verse in question places God as the inventor of human speech. Dismissing this view, he claims that the verse did not intimate a divine role in the inception of languages, but rather it was concerned with the characteristics of the anatomy of tongues ('Abd al-Jabbār 1969:553-4). His clarification of this verse in a way which supports istiläh is somewhat contrived but it is also indicative of the weight attached to countering traditional proofs. Scholarship from subsequent periods did speak of there being a contradiction of scriptural evidences germane to the two doctrines on the origin of languages; however, in the periods when the debate of the subject was at its most intense, it is evident that the scriptural evidence was viewed as favoring tawqif. A link had been created with the identity as well as the authority of the pious ancestors, making the case for the doctrine positively unassailable (Assmann 2006:73).

\section{Grammarians and philologists: contributions to the discourse}

While many of the aforementioned discussions on the origin of language have been predominantly gleaned from the works of theologians, it was in the literature of the Arabic grammarians, a number of whom were of Mu tazilite persuasion, that further analysis of the topic ensued. In a work devoted to a linguistic synthesis of the elements of the Arabic language, Ibn Jinnī (d. 1002), a grammarian of well-known Mu'tazilite leanings, includes a section on the origin of language. Ibn Jinni does preface his remarks on the subject by stating that it is a topic which calls for prudent deliberation, although he adds that most of the ahl al-nazar ("exponents of speculative theology"), whom we can take to mean the Mu'tazilites, were of the view that the origin of language lay in tawaduc (common agreement) and istilāh and not wahy (revelation) or tawqif (Ibn Jinnī 1952:I, 40-9). He then comments that his revered mentor, Abū 'Alī al-Fārisī (d. 987), a distinguished Mu'tazilite grammarian, actually admitted that language was "from God" (tawqiff), citing Q 2:31, "And indeed God taught Ādam the names (asmä) of all things." Ibn 
Jinnī does interject that one could infer from the verse that God empowered Ādam to establish language and that this was an additional view that even al-Fārisĩ professed in some of his discussions on the subject, as did the philologist Abū 'l-Hasan al-Akhfash al-Aṣghar (d. 927). Ibn Jinnī then proceeds to offer a traditional explanation of the Qur'anic verse in which it is stated that God taught to Addam the names of all things created in all languages and that he and his offspring had spoken these languages. Ibn Jinni goes on to state that consequently, as the offspring of Âdam dispersed throughout the world, they eventually adopted a particular language from among those original languages; the remainder of which became extinct. Ibn Jinnī insists that if authenticated reports affirm such a view, then it was incumbent to accept and believe in them, yielding to their import (Ibn Jinni 1952:I, 41; cf. Kopf 1956:34-6).

Ibn Jinni then sets out the theoretical thrust of the counter-position of muwäda'a, explaining how interlocutors would create connections between words and meanings by way of gesticulation; he explains they would point to one of the sons of Âdam and repeat themselves saying, "man, man, man" (insān). Interlocutors would progress through language in this way, defining in the process nouns, verbs, and particles. According to this view, a blueprint of muwäda' $a$ could then form the basis for different lexical codes, as selected words were assigned equivalences in other languages. The key prerequisite for all this was the existence of a language initially established through muwäda'a. Ibn Jinnī asserts that as far as the proponents of muwad $a^{\prime} a$ are concerned, it was improper to suggest that God could be the agent of positing due to the corporeal movement associated with gesticulation, which was an act imperative to the process of naming; this is because God has no physical organ (järiha). But it is speculated that God could transpose and transfer the use of established conventions, but again this would require the existence of an established language in the first place. Interestingly, Ibn Jinni proposes a solution to the predicament: was it not possible for God to create a sound in an entity or body which would then be used to identify and characterize that entity? He even points out that God would not need to repeat himself! Such an explanation would obviate the need for acts of physical gesticulation on the part of God. There appears to have been little enthusiasm for his suggestion as he explains that it 
was recognized as being merely possible. An alternative explanation for the origin of language is mentioned by Ibn Jinnī and it seems to be related to the naturalist thesis referred to in Plato's Cratylus, a dialogue which deals with the correctness of names and naming (Lepschy 1994:15-29; Versteegh 1997:108). In the Greek philosophical setting

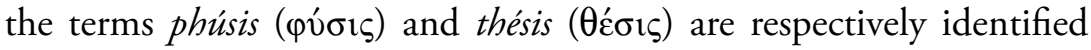
with naturalist and conventionalist perspectives. The former term predicates a natural affinity between words and meanings while, in contrast, thésis signifies that the connection between the two was purely arbitrary. The ensuing arguments hinged upon the nature of the relationship between words and their meanings within a broader context of nature and law, while in the Islamic context, the issue turns on the identification of the original designator of language. The Mu'tazilite theologian 'Abbād ibn Sulaymān championed the naturalist thesis and it is referred to by Ibn Jinnī as being a sound perspective. 'Abbād is reported to have spoken of a natural affinity between the collective phonemic constitution of words and their signified meanings to the extent that this intrinsic relationship determined the whole process of muwäda'a. In one example 'Abbād is asked what the Persian word for rock conjures up? He replies, "I find in (the word) connotations of aridity and solidity; I believe it to be a rock" (Suyūtī 1970:I, 47). The objection to this thesis was simple: if such a natural affinity existed, then all languages would be spontaneously understood by each and everyone. Abū Rashīd al-Naysābūrī reports that 'Abbād argued that changing the name of an entity leads to a change in its character and that his Basran cohorts deemed him asinine for his views (Naysābūrī 1979:161). Grammarians as early as al-Khalī ibn Ahmad were fascinated by forms of onomatopoeia as were later Basran luminaries (cf. Ibn Taymiyya 1961:418). Even Ibn Jinnī refined a theory of etymology (ishtiqāq) which was based around a common meaning intrinsic to the radicals of a particular verbal root and its permutations, a topic he expounds upon at length in this work (Ibn Jinnī 1952:II, 133-9).

Ibn Jinnī does not discuss the theological arguments about religious obligations and prerequisites; nor is there any reference to the debate about the use of analogical reasoning in respect of the divine names. The conspicuous absence of allusions to such themes would appear to indicate that the arguments on the issues were still evolving. The only 
theological aspect of the debate touched upon in Ibn Jinnîs work relates to muwäda' $a$ and its being linked with evident acts of gesticulation which would have crude anthropomorphic implications. Finally, having scrutinized the various theses on the origin of language, Ibn Jinni explains that his reflections and deliberations on the subject over a considerable period of time together with the authenticated scriptural evidences had led him to conclude that it (language) was "from God Almighty" and that in his soul the belief that it was revealed via tawqif had been strengthened. This admission would seem to confirm the measure of success achieved by the proponents of tawqif as they were able to present their doctrine as one of the touchstones of orthodoxy by virtue of anchoring it to the exegetical statements of the pious ancestors. Their memory and standing would assist in securing authority for tawqif, which could then be used as an effective counter-argument against istiliāh and the panoply of theological doctrines for which it was exploited. Ibn Jinnī was, of course, a contemporary of 'Abd al-Jabbār and sympathetic to the views of his Mu'tazilite peers. Other grammarians held similar views (Loucel 1963:275). It is the case that theological and legal sources from the 10 th/11th centuries reveal that scholarship was moving towards a position of neutrality (waqf) on the subject. However, for those of a stern religiosity, to speak of anyone other than God as the establisher ( $w \bar{a} d i)$ of language was tantamount to disbelief (Ibn Hazm 1985:V, 137). Such an attitude would ensure the enduring legacy of tawqiff, for despite the suggestion that the proponents of istiläh eventually prevailed, many of the arguments for which it was invoked were passionately denounced (Versteegh 1996b:27). Furthermore, the concept of tawqif had served as a potent weapon in the defense of orthodoxy yet it could still be unleashed by a process of restoration, making it seemingly a timeless construct. Indeed, those individuals who opposed the theory of metaphor on theological grounds were soon invoking tawqif as one of the arguments in the refutations they set out.

One of the staunchest defenses of tawqif was probably mounted by the Kufan grammarian Ibn Fāris (d. 1005). This was presented in a text devoted to examining selected linguistic features and conventions of the language of Arabic. Ironically, the work was dutifully dedicated to al-Șāhib ibn 'Abbād (d. 995), a wazir of Mu'tazilite inclinations who appointed 'Abd al-Jabbār as the state's jurisconsult. The work was produced 
in an historical period in which the Buwayhids, a Shi ite dynasty, were in the political ascendancy. The text begins with a section on tawqif and isțiläh which is prefaced by Ibn Färis with his profession that "the language of the Arabs (is based on) tawqif." As proof of this, the locus classicus of tawqiif, Q 2:31, together with a selection of glosses by leading Companion figures is cited. Ibn Färis endorses the explication of this verse typically associated with Ibn 'Abbās: namely that God taught Ādam the names of all created things (Ibn Fāris n.d.:7). Ibn Fāris deals with one objection raised by the opponents of tawqif relating to the fact that the Qur'anic verse states "and then he showed them to the angels," in which the pronoun for animate objects is employed, apparently betraying a restrictive element to the compass of names taught by God to Ādam. This phenomenon was explained by reference to the convention known as taghlïb ("predominance"): there was nothing restrictive about the use of this pronoun, because, having brought together all of creation, that which was animate predominated over that which was not and therefore the pronoun used for the former was applied.

Continuing with his emphatic endorsement of tawqîf, Ibn Fāris states that if someone were to ask whether the nouns for sabre (sayf), sword ( husamm), scimitar ( $a d b$ ), and other terms had their origins in tawqif and that none of these nouns was conventionally agreed upon, "We would say indeed that is our belief." To back this up he uses an argument of citation (ihtijajj). This centers on the notion that disputes concerning language usage and conventions are often settled by common agreement through recourse to earlier philological conventions and poetic precedents. Ibn Fāris then states that if language were established via muwäda $a$ and iștiläh, then the resort to iḥtijāj, adducing these older forms of usage would be no more authoritative than $i$ tijijaj sourced to commonly agreed forms of usage established presently by one's contemporaries. The point made here is that the prestige and authority commanded by older forms of usage seemingly determined via tawqif would be invalid; yet conventions in terms of deference to precedents show that the reverse is true. Within Ibn Färis's conception of tawqif scant attention is paid to refuting the theoretical arguments adduced by the proponents of istitiah, but rather the focus is deliberately placed upon highlighting the authority of traditional proofs endorsed through reference to the memory of the pious ancestors (salaf). Ibn 
Fāris makes an audacious claim that Arabic orthography, grammar, and the science of prosody owed their origins to tawqif, remarking that although conventional histories had associated their invention with notable scholars, such individuals had merely revived ancient disciplines of learning which had hitherto perished in time.

Ibn Fāris was an unquestionable defender of tawqîf, although it is fair to say that much of his theology seems informed by traditional Sunni orthodoxy. Abū 'Alī al-Fārisīi, Ibn Jinnī, and al-Akhfash al-Aṣghar were all of $\mathrm{Mu}$ 'tazilite persuasion, yet they were more than prepared to endorse tawqiff, despite their being ideologically close to the Basran Mu'tazilites. Moreover, during the same historical periods, Ash arite theologians and lawyers were now adopting a less hostile attitude to isțiläh. Theories abounded fusing the two principal theses on the origin of language, such as the one propounded by the Shafi ite scholar Abū Ishạa al-Isfarāyīnī (d. 1027) who championed the idea that God revealed a mandatory portion of language which enabled the process of iștilāḥ to proceed. Other distinguished theologians such as Abū Bakr al-Bāqillānī sanctioned a non-committal approach (Asnawī 1999:I, 190). The position taken by Mu tazilite grammarians in respect of the doctrine of tawqif would seem to contradict the idea that during the course of the 9th century and beyond there existed a tension between orthodoxy and arch-rationalists on the issue. But the grammarians appear as exceptions in this regard. Their inclination to tawqif was influenced by the fact that they were utterly enthralled and captivated by the language whose virtues and features they had spent a lifetime poring over and extolling. Placing that language on the plane of tawqif was inevitable; it provided a means of conceptually accentuating the inimitability of the language in which the sacred text had been revealed.

One sensitive issue raised by scholars such as Richard Frank and Kees Versteegh relates to the fact that the discussion of the origin of language did not receive much sedate reflection in the works of the Arabic linguists. It is linguistic literature from the late 10th century in which the topic is first reviewed. Frank sees the subject area as being inspired by theological considerations and hence its appearing in the works of the ahl al-kalàm (proponents of speculative theology) (Frank 1978:29). Versteegh takes the view that within the Islamic tradition such a subject was not considered paramount because a synchronic view of language 
prevailed among linguists. Scholars were concerned only in engaging with the revered language in which their sacred texts were revealed, a text they believed to have been preserved over the years by divine decree. They were purely interested in the applied linguistic aspects of scholarship in respect of that language, which to them was a statically preserved phenomenon (Versteegh 1996b:16-19; Weiss 1987:343). It has further been suggested that following the political demise of the Mu'tazilites, many of the movement's chief proponents took refuge in the vocations of law and, indeed, grammar, within which they were able to pursue their interests, influencing the discourse and ideas generated within these disciplines (Makdisi 1984:16; Versteegh 1996a:592). Whether this state of affairs helped precipitate the move to a position of neutrality (waqf) on the issue of the origin of language is debatable. One notes that despite the deference to tawqif among grammarians, elaborate philological theories which they developed did contradict the underlying gist of the theory. However, they continued to maintain an allegiance to the thesis; despite the fact that tawqif had not always been a distinction of religious orthodoxy, it was generated in the attempts to counter theological innovation by appealing to the exegetical musings of the pious ancestors (Shah 2000:60). It is worth mentioning the apparent linkage between isțilāh and the doctrine of a created Qurān. It has been claimed that istiläh was ideally suited to undermine the doctrine of an uncreated Qur'ān (Weiss 1974:38; Carter 1983:68; Versteegh 1996b:25; Vasalou 2009:204-5) and that there was likewise an affinity between the orthodox doctrine of an uncreated Qur'ān and the espousal of tawqif. However, within the body of classical literature such linkage appears to be of marginal importance to the main protagonists and therefore unlikely to have been a driving factor in the ensuing debates.

\section{Renaissance of tawqīf}

In a treatise devoted to a refutation of the incidence of metaphor in the language of Arabic, the medieval theologian and Hanbalite scholar Ibn Taymiyya (d. 1328) includes references to the doctrines of tawqif and istiläh, referring to the fact that these two theses gained ascendancy in classical Muslim discourse on the origins of language. Ibn Taymiyya 
emphasized that istilāh was a detrimental innovation, explaining that the first individual to profess it was Abū Hāshim. Ibn Taymiyya explains that both al-Ash 'arī and Abū Hāshim had been students of al-Jubbā'ī, but that al-Ash arī had subsequently denounced the Mu'tazilites and their major theological doctrines (Ibn Taymiyya 1983:82). He comments that the two students disputed over the issue of the origin of languages (mabdà al-lughāt): Abū Hāshim stated that language was the product of istiliāh while al-Ash arī responded that it was established through tawqif. Ibn Taymiyya observes that in later medieval periods scholars continued to debate the subject with some individuals arguing that the origin of language could be attributed to combined measures of both tawqif and istiläh, reporting that many scholars adopted a position of neutrality (waqf) on the issue. His reference to tawqif and isțiläh is broached as part of his wider critique of the concept of metaphor or trope (majazz), which was rejected by certain theologians (Ghazāli 1971:74). Rational theologians were making frequent references to metaphors in order to obviate the anthropomorphic imagery presented by sensitive scriptural dicta (Heinrichs 1992:256-7).

The brand of conservative theology to which Ibn Taymiyya subscribed maintained that this resort to metaphor was an insidious attempt to promulgate heretical doctrines. Thus, in instances where there were Qur'anic verses referring to God's face or hands, applying metaphor would render the former as being a reference to His essence, while the latter would be interpreted as divine grace; consequently, the device of metaphor permitted the circumvention of the literal language of scripture. Additionally, lexical evidence in the form of loci probantes could be readily adduced to show that such explanations were consistent with the ancient usage of the Arabs. For the conservatives, while accepting the need to differentiate between divine and human dimensions of attributes and traits, it was deemed improper to explain away references to God in this way. Ibn Taymiyya was of the view that such instances had to be accepted bi-lä kayf ("without qualification"); namely, if God describes Himself as descending through the heavens, this descent should be accepted as defined in scripture without expressing a view about the precise nature of its modality. Those who argued that it was imperative to explain away the literal language in such instances would place such examples within the vector of majazz, stating that this was an 
example of God's "mercy" descending through the heavens. ${ }^{5}$ Sensing the potency of the device of metaphor in the service of speculative theologians such as the Mu'tazilites and others, Ibn Taymiyya set out to demolish conceptually the idea that metaphor was a feature of the Arabic idiom and the conspicuous reference to the doctrine of tawqif provided a subtle means of insinuating not only that there was an innovative quality to iștiläh, but also that configured around it was an array of theologically contentious notions. By a process of renaissance tawqif was again made relevant.

Although there has been a tendency to identify Ibn Taymiyya with a rigorous interpretation of tawqif, and one which is typical of the conservatism with which he is often associated (Weiss 1974:40), his explication of tawqif is hardly as strict as the emphatic endorsement of tawqif defined by Ibn Fāris. One needs to bear in mind that the aim of Ibn Taymiyya's disquisition on metaphor was to attack the use of majazz as a theological instrument and, in the doctrine of tawqijf, he found a convenient accessory for his arguments. Rhetoricians divided words into haqüqa ("veridical") and majāz ("metaphorical" or "figurative") senses; the former applied when a word's usage was consistent with its primarily assigned meaning. The technical definition of a metaphor was a word or phrase which was used in a secondary sense other than its primary one; the term majaz conjures up the image of transfer or movement from one meaning to a second one and it is likewise exemplified by instances of borrowing (isti' ära). Hence, if one were talking about a lion in its haqiqa sense, then this would be a reference to the tawny colored predator that belongs to the family of cats known for their ferociousness; conversely, if one were using the term in its majäz sense, then it would be the qualities of courageousness and valor that were intended (Abū 'l-Ḥusayn al-Bașrī 1991:12).

Ibn Taymiyya's reasoning is that, while the semantic compass of such terms was wholly valid, it was not necessary to construct a haqiqa-majäz division to determine such meanings; he proposed that the division of words and expressions into haqqiqa and majäz classes was a later development which owed its origins to the activities of groups such as the

5) This would be classed as exemplifying majāz al-ḥadhf (an elliptical metaphor): 'mercy' is the elided element which obviates the anthropomorphic sense of the expression. 
Mu'tazila and that there were ulterior motives driving the associated discourse. The general thrust of Ibn Taymiyya's critique rested on his chipping away at the theoretical edifice constructed to define majāz and haqiqa through reference to primary and secondary cycles of posited meanings which were technically connected with muwäda'a. Appealing to the authority of precedent, he maintains that among the pious ancestors no specific reference to these terms is found in the technical sense of metaphorical or veridical usage; thus although some scholars such as Abū 'Ubayda (d. 825) and Ahmad ibn Hanbal (d. 855) actually utilized the term majaz, they were not referring to metaphor but rather a rudimentary tool of linguistic interpretation and analysis (cf. Heinrichs 1984:122-5). The contention that majazz was not a feature of the Qur'ān or, indeed, the Arabic language was principally propounded by scholars associated with the Zāhirī tradition, a theological movement which also condemned the use of analogical reasoning in all religious matters (Asnawi 1999:1.302). ${ }^{6}$ Interestingly, many of those who rejected iștilāh, such as Ibn Khuwazmandād, were actually opponents of the concept of metaphor. It is also the case that philological concepts discussing the incidence of synonyms (taräduf), homonyms (ishtiräk), antonyms ( $a d d \bar{a} d)$, and etymology (ishtiqa $q$ ) in the language of Arabic were vehemently opposed by some defenders of tawqif. They were of the view that these concepts per se presupposed a deficiency or inherent flaw in the design of language.

Having spent some time outlining the standard definitions of majazz and haqiqa, the point is made that such definitions presupposed an acute awareness of the stages of positing meaning and the "givenness" of language. It suggests that a word was first used for one meaning before being transferred to another. Ibn Taymiyya presents the argument that such a view would be in accordance with the beliefs of those who professed that languages were based on iștiläh: namely, that a group of intelligent individuals came together and commonly agreed upon the designation of words and meanings, applying them to all languages; this, in his estimation, was a view no one before Abū Hāshim actually

6) Dāwūd b. Khalaf al-Zāhirī (d. 883) is the founder of this movement and his son Abū Bakr b. Dāwūd al-Iṣfahānī rejected that majāz featured in the Qurāan or the traditions. 
held. Ibn Taymiyya protests that it is impossible to state categorically that people actually came together and assigned all the lexical items found in all languages with their posited meanings before actually using them. His conclusion is that all one can ascertain, in the sense of broad authentication, is that certain words are employed (isti mäl) for specified meanings and nothing else (Ibn Taymiyya 1983:82-6).

Ibn Taymiyya seems to accommodate a greater measure of flexibility in explaining the historical evolution of language for he recognizes that a rigidly formulated doctrine of tawqiif could never be fully substantiated through reference to the scriptural sources. Thus, in many ways, his critique of istiläh rests upon underscoring its innovative texture. He does see tawqi if as being emblematic of a divinely inspirational dynamic which accounts for both the establishment of language and its subsequent acquisition. He even uses the Arabic word ilhäm ("inspiration") alongside tawqif to highlight this process. Within such an interpretation, the notion that istiläh, together with its concomitant phases of muwäda $a$, serves as the sine qua non for the use of language is rendered redundant. Nonetheless, the inference is not that all languages are traced back to Ādam but rather that humans were imbued with an innate capacity to express and communicate desires and thoughts through the medium of words, adding that ilhäm sufficiently explains the ability to articulate language without pre-existing muwāda' $a$; in essence, this explanation is the embodiment of his thesis of tawqi $f$ (Ibn Taymiyya 1983:86).

The critique of majazz outlined by Ibn Taymiyya was taken up with alacrity by his loyal student Ibn Qayyim (d. 1350). Prominent in his treatment of this subject is the view that the majority of scholars (al-jumbür) were of the belief that language was revealed via tawqif (Ibn Qayyim 1990:233); the reference to this doctrine's having been the preferred dogma of the pious ancestors formed one of the first structured phases of his critique of majaz. Ibn Qayyim was not concerned with launching into an energetic defense of the revelationist view of language, but, like his mentor, his focus was upon dismissing the possibility that one could unravel successive cycles of conventionally positing words with meaning. What is striking about Ibn Qayyim's treatment of the topic is not only his marshalling of all the technical arguments for and against majaz together with the theological import 
of the discussions, but also his reference to the theory of majaz being an innovation which occurred after the (preferred) first three centuries of the Islamic tradition. He is naturally alluding to the Prophetic utterance in which mention is made of the finest of centuries being the one in which the Prophet lived followed by the two ensuing centuries. The inference is that the authenticated precedents, beliefs, and practices defined in these select periods are authoritative and even sacrosanct. Given their historical genesis and provenance, neither majäz nor istiliāh could claim this coveted status; conversely, the thesis of tawqif enjoyed the imprimatur of community consensus (Ibn Qayyim 1990:233). In this sense the hierarchy of authority created by reference to the identity of the pious ancestors provided critical leverage for tawqif and Ibn Qayyim could build on this before commencing with the theoretical case against majāz.

\section{Conclusions}

In the context of the classical articulation of orthodox Islam, the normative practices and beliefs of the faith were ultimately anchored to and informed by a synthesis of Quranic and Prophetic paradigms. Within this hierarchy of authority, apposite importance was attached to the teachings and musings of the pious ancestors, namely, those individuals who were either Companion figures or individuals among later generations of adherents of the faith. Certainly, within the realm of speculative theology many of the arguments and points of dispute were the product of dialectical discussions and postulates; yet, where possible, it was still relevant to seek a point of reference or support for such ruminations in the traditional sources. The so-called adillat al-sam ("proofs from the authenticated corpuses of scripture") were the desideratum for the resolution of theological quandaries, although groups with conflicting ideologies would resort to interpreting such proofs in a manner commensurate with their preconceived views. This is certainly the case for the history of arguments about the origin of language. The thesis of istilath served as a platform for theologically contentious doctrines, including arguments about the imposition of religious and moral obligations, the nature of the divine names and attributes, the employment 
of metaphor, and, in the view of some, the doctrine of a created Qur'àn. The developed doctrine of tawqif was made authoritative by its being seemingly cast through a reconstruction of the past and presented as a distinction of orthodoxy; the accentuation, explication, and contextualization of general scriptural evidences made this reconstruction of the past possible. The less stringent attitude adopted by many theologians to the espousal of either the concept of tawqiff or isțiläh did not diminish the orthodox pedigree of the former doctrine in terms of its being reminiscent of the memory of the pious ancestors. Moreover, that the thesis of tawqi $f$ was invoked when needed as an emblem of traditional orthodoxy, no more so than in the discussions on the incidence of metaphor in the language of Arabic, would seem to underline the role that referencing to the past and the processes of generation historically played in the defense of orthodoxy.

\section{References}

Primary Sources

'Abd al-Jabbār, al-Qāḍi Aḥmad al-Asadābādī. 1965. Al-Mughnī fì abwāb al-tawhīd wa'l-adl, vol. 5, ed. Maḥmūd Muhammad al-Khuḍayrī. Cairo: al-Dār al-Miṣriyya li'l-Ta'lif wa'l-Tarjama.

- 1969. Mutashābih al-Qữān, ed. Muhammad Zarzūr. Cairo: Dār al-Turāth.

Abū 'l-Ḥasan al-Ash arī. 1990. Maqualāt al-Islämiyyìn, ed. M. 'Abd al-Ḥamīd. Beirut: al-Maktaba al-Așriyya.

Abū 'l-Ḥusayn al-Bașrīi, Muhamamad b. 'Alī. 1991. al-Mu'tamad fi ușül al-fiqh, 5 vols., ed. Khalīl al-Mays. Beirut: Dar al-Kutub al-'Ilmiyya.

Al-Āmidī, Sayf al-Dīn. 2004. Ghāyat al-marām fì 'ilm al-kalām, ed. A Farīdī. Beirut: Dār al-Kutub al-'Ilmiyya.

Asnawī, Jamāl al-Dīn 'Abd al-Rahīm al-. 1999. Nihāyat al-sūl fì sharh minhāj al-wusūul ilā 'ilm al-uṣūl, 2 vols., ed. Shábān Muhammad Ismāî̀l. Beirut: Dār Ibn Hazm.

Baghdādī, 'Abd al-Qāhir al-. 1928. Kitāb ușūl al-dīn. Istanbul: Madrasat al-Ilāhiyāt Bi-Dār al-Funūn.

Bāqillānī, Abū Bakr b. Tayyib al-. 1993. Kitāb Tamhīd al-awāil wa-talkhīs al-dalā̉il, ed. 'Imad al-Dīn Aḥmad b. Haydar. Beirut: Mu'assasat al-Kutub al-Thaqāfiyya.

Ghazālī, Abū Hạ̄mid al-. 1971. al-Mankhūl min tà lìqāt al-usūl, ed. M.H. Haytū. Beirut: Dār al-Ḥadīth.

- 2006. Al-Maqșad al-asnā sharh asmä̀ Allāh al-ḥusnā, ed. Muhammad al-Nawāwī. Cairo: Maktabat al-Fajr al-Jadīd. 
Ibn 'Asākir, Abū 'l-Qāsim 'Alī b. al-Ḥasan, 1991. Tabyīn Kadhib al-muftarī fìmā nusiba ilā al-imām Abì 'l-Hasan al-Ash'arī. Beirut: Dār al-Kitāb al-'Arabī.

Ibn Fāris, Abū 'l-Ḥusayn Aḥmad b. Zakariyyā'. n.d. al-Ṣäḥibi fì fiqh al-lugha 'l- 'arabiyya wa-sunan al-'Arab fì kalāmihā, ed. Aḥmad Șaqr. Cairo: Dār Ihyā' al-Kutub al-'Arabiyya.

Ibn Fūrak, Abū Bakr Muhammad b. al-Ḥasan. 1987. Mujarrad maqālat al-shaykh Abī 'l-Hasan al-Ash'arì: (exposé de la doctrine d'al-Ash'arî), ed. D. Gimaret. Beirut: Dar el-Machreq.

Ibn Hazm, Abū Muḥammad 'Alī b. Aḥmad. 1985. al-Fisal fì l-milal wa'l-ahwä̀ wa'lniḥal, 4 vols. ed. Muhammad Naṣr and 'Abd al-Raḥmān al-'Umayra. Beirut: Dār al-Jìl.

Ibn Jinnī, Abū 'l-Fatḥ 'Uthmān. 1952. al-Khasăà is, ed. Muḥammad 'Alī al-Najjār, Cairo: Maţba'at Dār al-Kutub al-Miṣriyya.

Ibn Qayyim, Shams al-Dīn Abī 'Abd Allāh. 1990. Al-Șawā̉ iq al-mursala 'alā al-jahmiyya wa'l-mu'attila. Beirut: Dār al-Kutub al-'Ilmiyya.

Ibn Taymiyya, Aḥmad b. 'Abd al-Ḥalīm. 1983. Kitāb al-İmān. Beirut: Dār al-Kutub al-'Ilmiyya.

Isfarāyīnī, Abū 'l-Muẓaffar al-. 1999. al-Tabșìr fìl-dìn wa-tamyīz al-firqa al-nājiya 'an al-firaq al-hālikìn, ed. Muhammad al-Kawtharī. Cairo: Al-Maktaba al-Azhariyya lil'l-Turāth.

Jurjānī, al-Sharîf 'Alī b. Muhammad al-. 1998. Sharḥ al-Mawāqif, 4 vols. in 8 parts, ed. Mahmūd 'Amr al-Dimyātī. Beirut: Dār al-Kutub al-'Ilmiyyah.

Juwaynī, Abūl-Ma ālī 'Abd al-Malik al-. 1969. al-Shāmil fì usūul al-dìn, ed. Sāmī al-Nashshār, Fayșal Budayr 'Awn, Suhayr Muhạmmad Mukhtār. Alexandria: Munsha’at al-Maārif.

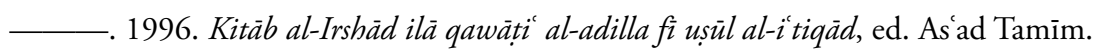
Beirut: Mu'assasat al-Kutub al-Thaqāfiyya.

Mānkdīm Shashdīw, Aḥmad b. al-Ḥusayn. 1965. Kitāb sharh al-usūl al-khamsa. Commentary by Mānkdīm Shashdīw, Aḥmad b. al-Ḥusayn, ed. 'Abd al-Karīm 'Uthmān. Cairo: Maktabat Wahba. (The text is often attributed to 'Abd al-Jabbār)

Naysābūrī, Abū Rashīd Sa īd b. Muhammad ibn Sa'īd. 1979. al-Masă il fìll-khiläfbayn al-Bașriyinn wa'l-Baghdādiȳ̃n, ed. M. Ziyāda and R. al-Sayyid. Beirut: Ma'had al-Inmä al-'Arabī.

Qurțubī, Abū 'Abd Allāh Muhammad al-Anșāin al-. 1988. al-Jāmi lì aḥkām al-Qur̉àn, 21 vols. Beirut: Dār al-Kutub al-'Ilmiyya.

Rāzī, Fakhr al-Dīn Muhammad ibn 'Umar al-. 1988. al-Maḥsūl fì 'ilm al-usūul, 2 vols. Beirut: Dār al-Kutub al-'Ilmiyya.

—. 1981-83. Mafätīḥ al-Ghayb. 16 vols., 32 parts. Beirut: Dār al-Fikr.

Suyūṭī, Jalāl al-Dīn 'Abd al-Raḥmān al-. 1970. al-Muzhir fí 'ulūm al-lugha wa-anwā̄ ihā, 2 vols., ed. Jād al-Mawlā, M.A., al-Bajāwī, A.M., Ibrāhīm, M.A. Cairo: Dār Ihyyā’ al-Kutub al-'Arabiyya.

Tabarī, Abū Ja far Muhammad b. Jarīr al-. 1969. Jāmi al-Bayāan 'an tà wìl ày al-Qur'ān, 16 vols. ed. Ahmad Muhammad Shākir. Cairo: Dār al-Ma'ārif. 
Zarkashī, Badr al-Dīn Muhammad b. Bahādir b. 'Abd Allāh al-. 1992. Al-Baḥr al-muhīt fì usūl al-fiqh, 8 vols., 2nd edition, ed. 'Abd al-Qādir al-'Ānī. Kuwait: Wazārat al-Awqāf Wa'l-Shu’ūn al-Islāmiyya.

\section{Secondary Sources}

Assmann, Jan. 2006. Religion and Cultural Memory: Ten Studies, trans. Rodney Livingstone. California: Stanford University Press.

Brunner, Rainer. 2005. "The Role of ḥadith as Cultural Memory in Shīì History." Jerusalem Studies in Arabic and Islam 30: 318-60.

Burrell, D. and Daher, N. 2004. Al-Ghazälì: the Ninety-Nine Beautiful Names of God. A Translation of al-Maqșad al-asnā fì sharh asmä Allāh al-ḥusnā, Gth edition. Cambridge: Islamic Texts Society.

Carter, Michael. 1983. "Language Control as People Control in Medieval Islam: The Aims of the Grammarians in their Cultural Context." In Arab Language and Culture, ed. Ramzi Baalabaki. Beirut: American University of Beirut, 65-84.

Frank, Richard. 1991. "Elements in the Development of the Teaching of al-Ash arī." Le Muséon 104: 141-90.

-1978. Beings and Their Attributes: the Teaching of the Basrian School of the Mu'tazila in the Classical Period. Albany: State University of New York Press.

Gimaret, Daniel. 1988. Les noms divins en Islam: exégèse lexicographique et théologique. Paris: Cerf.

Heinrichs, Wolfhart. 1984. "On the Genesis of the haqiqa-majäz Dichotomy." Studia Islamica 59: 111-40.

- 1992. "Contacts between Scriptural Hermeneutics and Literary Theory in Islam: the Case of Majāz." Zeitschrift für Geschichte der Arabisch-Islamischen Wissenschaften/Majallat Tà rìkh al-'Ulüm al-'Arabiyya wa'l-Islamiyya 7: 253-84.

Kopf, Lothar. 1956. "Religious Influences on Mediaeval Arabic Philology." Studia Islamica 5: 33-59.

Lepschy, Giulio. 1994 (ed.). History of Linguistics: the Eastern Traditions of Linguistics. Vol. I. London, New York: Longman.

Loucel, Henri. 1963. "L’origine du langage d'après les grammairiens arabes." Arabica 10: 188-208 and 253-81.

Madelung, Wilferd. 1974. "The Origins of the Controversy Concerning the Creation of the Qurān." In Orientalia Hispanica: sive studia F M Pareja octogenario dicata, ed. Félix M. Pareja Casañas. Leiden: E.J. Brill, 504-25.

Makdisi, George. 1962. "Ash'arī and the Ash'arites in Islamic Religious History." Studia Islamica 17: 37-80.

1984. "The Juridical Theology of Shāfi î: Origins and Significance of Ușūl al-fiqh." Studia Islamica 59: 5-47.

Peters, J.R. 1976. God's Created Speech: a Study in the Speculative Theology of the Mù tazilì Qādì al-Qudàt Abù l-Hasan 'Abd al-Jabbār ibn Aḥmad al-Hamadānī. Leiden: E.J. Brill. 
Shah, Mustafa. 2000. "The Philological Endeavours of the Early Arabic Linguists: Theological Implications of the tawqif-iștiläḥ Antithesis and the majäz Controversy." (Part II) Journal of Quranic Studies 2: 44-66.

- 2007. "Trajectories in the Development of Islamic Theological Thought: the Synthesis of Kalām.” Religion Compass 2: 430-454. www.blackwell.com/ religioncompass.

van Ess, Josef. 1987. “Mu'tazila.” In Encyclopedia of Religion, ed. Mircea Eliade. New York: Macmillan Press, 6317-25.

Vasalou, Sophia. 2009. "Their Intention was Shown by Their Bodily Movements: The Basran Mu'tazilites on the Institution of Language." Journal of the History of Philosophy 47: 201-21.

Versteegh, Kees. 1977. Greek Elements in Arabic Linguistic Thinking. Leiden: E.J. Brill. - 1996a. "The Linguistic Introduction to Rāzìs Tafsìr." In Studies on Near East Languages and Literatures. Memorial Volume Karel Patracek, ed. Petr Vavrousek and Petr Zemanek. Prague: Academy of Sciences of the Czech Republic, BCS Printing, 589-603.

- 1996b. "Linguistic Attitudes and the Origin of Speech in the Arab World." In Understanding Arabic: Essays in Contemporary Arabic Linguistics in Honor of El-Said Badawi, ed. Alaa El-Gibali, Cairo: The American University in Cairo Press, 15-31.

- 1997. Landmarks in Linguistic Thought III: the Arabic Linguistic Tradition. London, New York: Routledge.

Watt, William Montgomery. 1998. The Formative Period of Islamic Thought. Oxford: Oneworld Publications. (reprint of the 1973 edition).

Weiss, Bernard. 1974. "Medieval Muslim Discussions of the Origin of Language." Zeitschrift der deutschen morgenländischen Gesellschaft 124: 33-41.

1987. 'Ilm al-wad': an Introductory Account of a Later Muslim Philological Science." Arabica 34: 339-56. 